\title{
Test Of AntiInjury Activity Ethanol Extract Of Jatropha Multifida L Against Open Wound On Rabbit's Back
}

\author{
Setia Budi ${ }^{[1]}$, Noval $^{[2]}$ \\ \{setiabudi2191@gmail.com, novalhalim10@gmail.com, \\ ${ }^{[1,2]}$ Departemen of Pharmacy, Faculty of Health, Universitas Sari Mulia, Banjarmasin, Kalimantan \\ Selatan
}

\begin{abstract}
When the wound arises there are some effects that will arise such as the loss of all or part of the organ function, bacterial contamination. Wound healing can be accelerated with the use of traditional medicine. Some traditional remedies such as iodine plant (Jatropha multifida L) can accelerate wound healing maximally. Method: This type of research is a laboratory experiment conducted on test animals based on Completely Randomized Design (RAL). Processing for wound healing data processing is analyzed using Anova (One Way Anova). With exstract consentration 25\%, 50\% and 75\% Result: Based on this research can be concluded that the formulation of ointment extract of iodine plants fulfill the requirements of the ointment qualities ranging from organoleptic test, homogeneity test and $\mathrm{pH}$ test. $25 \%, 50 \%$ and $75 \%$. Anti-wound ointment with a concentration of $75 \%$ Conclusion: Anti-wound ointment with a concentration of $75 \%$ gives the best wound healing effect in comparison with other test preparations.
\end{abstract}

Keyword. rabbit's back, Jatropha multifida L, ointme

\section{Introduction}

Damage to a portion of the body's tissues where there is specific tissue substance that is damaged or lost is a wound condition. When wounds arise either acute or chronic wounds there are several effects that will arise such as loss of all or part of organ function, sympathetic stress response, bleeding and blood clots, bacterial contamination, and cell death [1].

Acute wounds are injuries that occur in tissue that can recover a minimum of 8-12 weeks. The main cause of acute injury is mechanical injury due to external factors, which occur contact between the skin with a hard or sharp surface, open wounds, and post-operative injuries. Other causes of acute injuries are burns and chemical injuries, such as exposure to radiation rays, electric shock, exposed to corrosive chemicals.

This will get worse if there is no further response to the wound. The impact of a wound from a rusty object is irritation, infection, inflammation, fever and the worst effect is tetanus [1].

Wound healing can be accelerated by the use of medicinal plants. Some medicinal plants such as iodine (Jatropha multifida L) which can accelerate wound healing. This will be an increase in the use of traditional medicine because traditional medicine has side effects or undesirable effects smaller than chemical drugs [2]. 
In research conducted by Adesola and Adetunjin. (2007) examined the effectiveness of iodine plants against sufferers of infections caused by bacteria. Comparing the effectiveness with antibiotics that are often used in this case, the results obtained are that this plant is more effective than the antibiotics commonly used.

The wound healing process is not only limited to the local regeneration process, but is also influenced by endogenous factors, such as age, nutrition, immunology, drug use, and metabolic conditions. The wound healing process is divided into five stages, including the stages of homeostasis, inflammation, migration, proliferation, and maturation [2].

This study aims to determine the anti-wound activity of the iodine plant (Jatropha multifida $\mathrm{L}$ ) and is expected to provide information and scientific evidence on the use of iodine as herbal medicine or traditional medicine.

\section{Research Stages Collection}

Determination and processing of materials. Making ethanol extract of iodine (Jatropha multifida L.) leaves by maceration method. Making test preparations.

Testing the antiluka effect of ethanol extract of iodine (Jatropha multifida L.) leaves Data processing: for wound healing data processing was analyzed using Anova (One Way Anova).

\subsection{Tool}

Analytical scales, blenders. Rabbit cage, jar, set of measuring flask, beaker glass, test tube, rabbit cage, evaporator, mortar, stemper, ointment container, horn spoon, erlenmayer, plastic cup cover, maserator, stirring rod, filter paper, vaporizer cup, oven, vacuum, separating funnel, spatula, water bath, spoit, scissors, tweezers, capillary tubes, dropper pipettes, glass objects and microscopes.

\subsection{Material}

Simplisia plant iodine (Jatropha multifida L.) aquadest, ethanol 96\%, sterile aquadest, kalmicetine, $\mathrm{H} 2 \mathrm{SO} 42 \mathrm{M}, \mathrm{NaOH} 10 \%, \mathrm{NaOH} 15 \%, \mathrm{FeCl} 3$ vaseline albumin and lanae adeps.

\subsection{Experimental Animals}

The experimental animal used was a rabbit (Oryctolagus cuniculus) Rex strain with a weight of 1-1.5 $\mathrm{kg}$, aged 4-10 months.

Material Storage And Determination

The iodine plant (Jatropha multifida L.) used for the study was obtained from the Manoko Lembang plantation and was carried out in the determination of plants in the ITB Biological Taxonomy Laboratory. Extraction

Simplisia dried iodine (Jatropha multifida L.) as much as $1 \mathrm{~kg}$ is mashed to powder form, then extracted using a maceration method using $96 \%$ ethanol solvent at room temperature for $3 \times 24$ hours, where every $1 \times 24$ hours filtered, then the solvent is replaced with a new solvent. The liquid extract obtained is then evaporated at a temperature of $40-50^{\circ} \mathrm{C}$. Amendment calculation:

Randemen: (extract weight) / (weight of simplicia) x 100\%

Phytochemical screening

1. Identification of Alkaloids

As much as $2 \mathrm{~g}$ of simplicia powder was moistened with $25 \%$ ammonia and $20 \mathrm{~mL}$ chlorofrom added, then crushed. Filtered mixture. The filtrate was extracted with $10 \% \mathrm{HCl}$, then the acid layer was taken, divided into different tubes in each test tube:

Added a few drops of Mayer reagent formed white precipitate. Added some dragendroff reagents formed brick red deposits. 


\subsection{Identification of Flavonoids}

A total of $1 \mathrm{~g}$ of simplicia powder in $100 \mathrm{~mL}$ of water is boiled for 5 minutes and filtered. Hereinafter referred to as solution $\mathrm{C}$, then into $5 \mathrm{~mL}$ of solution $\mathrm{C} \mathrm{a} 21 \mathrm{HCl} 2 \mathrm{~N}$ magnesium powder was added. Then shake with $10 \mathrm{~mL}$ of amyl alcohol. Positive reactions are indicated by orange, red or yellow in the amyl alcohol layer.

1. Identification of Saponins

A total of $100 \mathrm{~mL}$ of $\mathrm{C}$ solution in the test tube is shaken vertically for 10 seconds and let stand. The presence of saponins is indicated by the formation of stable foam.

2. Identification of tannins

$5 \mathrm{~mL}$ of $\mathrm{C}$ solution was reacted with $1 \% \mathrm{FeCl}$. If blackish blue is formed indicates tannin.

3. Identification of Kuinon

As much as $5 \mathrm{~mL}$ of $\mathrm{C}$ solution was added a few drops of $1 \mathrm{~N} \mathrm{NaOH}$ solution. The existence of a quinon is indicated in red.

4. Identification of steroids / triterpenoids

Simplisia powder were weighed as much as $1 \mathrm{~g}$, macerated with $20 \mathrm{~mL}$ ether for 2 hours, filtered. The filtrate was evaporated with a vaporizer cup and the remaining Lieberman-buchard reagent was added through the cup wall. If a purple or red color turns blue or purple, blue indicates a triterpenoid / steroid (Saifudin, 2014).

\section{Wound Making}

Making a wound on the back of a rabbit by making an incision along the $\pm 2.5 \mathrm{~cm}$ square parallel to the spine (os vertebrae) using a sterile scalpel. Before treatment, the hair around the back is shaved and cleaned with alcohol, and anesthetized. Wounds made include stage III wounds, which are overall skin loss including damage to subcutaneous tissue that can extend to the bottom but do not cross the underlying tissue (Eka Mulya et al, 2010).

Measurement of Average Length of Open Wounds

Measurement of the average diameter of an open wound was done by $\mathrm{dx}(1,2,3)$, which is the diameter of an open wound at each treatment repeat. Calculated by the formula: $\mathrm{dx}=(\mathrm{dx}(1)$ $+d x(2)+d x(3)) / 3$ for the average diameter of an open wound $(\mathrm{cm})$. Statistically the data were analyzed by the ANOVA (Analysis Of Variant) method with $\alpha 0.05$ or $5 \%$ with the formula: $\mathrm{P} \%=(\mathrm{do}-\mathrm{dx}) / \mathrm{do} \times 100 \%$, where $\mathrm{p} \%$ is for the percentage of wound healing. If there is a significant difference then proceed with the LSD (Least Significant Different) test to see which treatment gives a different effect. (Grace Riani, et al. 2012).

Testing Anti-wound Activity

Observation was carried out for 24 hours to see the infection and rapid recovery of the wound that had been made, after observing the infection and wound recovery then observed for 30 days for wound healing. Observation of this wound is done before administration and after treatment until there are signs of healing by measuring the length of the wound that has been made.

Each rabbit is given the following treatment:

Treatment A: Open wounds were given iodine plant extract $100 \mathrm{mg}$

Treatment B: Open wound was given iodine plant extract $250 \mathrm{mg}$

Treatment C: Open wound was given a 500mg iodine plant extract

Treatment D: Open wound was given povidone iodine ointment (Positive Control).

Treatment E: Open wound was given an ointment base (Negative Control).

\section{Results and Discussion}


In this anti-wound activity research, iodine plant ethanol extract was used as a test preparation. The iodine plant used was obtained from Manoko, Lembang. According to research iodine plants are best harvested at the age of 6-7 months to obtain the optimal levels of the most active compounds. Then the determination was carried out in the Biological Taxonomy Laboratory of ITB. The results of the determination show that the material used in this antiwound activity test was true iodine plant (Jatropha multifida L) as shown in appendix 2. After being determined, the wet simplicia of the $5 \mathrm{~kg}$ iodine plant was chopped in order to expand the surface of the iodine plant so that it was dry and easy Dry simplicia obtained $1 \mathrm{~kg}$ of iodine plants, then proceed with the determination of water content which is one of the good extraction parameters. The aim is to provide a minimum limit or range of the amount of water content in the material. The value or range obtained is related to the purity and contamination $\leq 10 \%$ and the results of the test of the water content of iodine plant extract $4.6 \%$ which means that the extract used has met one of the requirements of good extract quality and phytochemical screening. The aim is to find out the secondary metabolite content of the iodine plant and the results show that the ethanol extract of the iodine plant contains secondary metabolites as shown in the table below:

Phytochemical Screening Results of Iodine Leaves

$\begin{array}{lll}\text { Secondary } & \text { Results } \\ \text { metabolites }\end{array}$

\begin{tabular}{lcl}
\hline 1 & Alkaloid & + \\
\hline 2 & Flavonoid & + \\
\hline 3 & Tannin & + \\
\hline 4 & Saponin & - \\
\hline 5 & Triterpenoid & - \\
\hline 6 & Steroid & - \\
\hline 7 & Polifenol & + \\
\hline
\end{tabular}

Signifying the test group compared with the positive group there was a significant difference (P $<0.05)$.

All treatment groups from day 1 to day 7 experienced changes in wound length or experienced wound healing, this is shown in the wound healing table from day 1 to day 7 where the wound gradually healed until the day to 7 obtained significant data was shown in the povidone iodine ointment treatment group (positive control) with $25 \%, 50 \%$ and $75 \%$ iodine plant ethanol extract ointment, compared with the basic ointment treatment group (negative control). That means the ointment of ethanol extract of iodine plants which basically contains alkaloids, flavonoids contained in plants according to iodine where the mechanism of flavonoids as antimicrobial substances is by poisoning the protoplasm damaging and penetrating the cell wall so that it accelerates healing and prevents infection. Tannins that function as an adstringen can cause shrinkage of skin pores so as to accelerate the wounding edge and polyphenols work capable of breaking peptidoglycan bonds in penetrating cell walls and causing leakage of cell nutrients such as proteins and pospolipida resulting in damage to bacterial cell membranes preventing infection that accelerates healing Folifenol wounds also work as antioxidants that accelerate the recovery of cell damage that occurs due to traumatic responses from wounds. If folipenol works properly, it will accelerate blood circulation so that blood can flow into the area where the wounds stimulate fibroblasts to heal wounds, povidon iodine which is able to heal open wounds and infections. skin lesions caused by bacteria (Darmawi et al, 2010). 
Measurement of the average diameter of wounds on the 14th day

\begin{tabular}{|c|c|c|c|c|c|}
\hline \multirow{2}{*}{ Goup } & \multicolumn{3}{|c|}{ Diameter wound } & \multirow{2}{*}{$\begin{array}{c}\text { Total } \\
\text { Diam } \\
\text { eter }\end{array}$} & \multirow{2}{*}{$\begin{array}{l}\text { Diamet } \\
\text { er of } \\
\text { the } \\
\text { wound }\end{array}$} \\
\hline & $\begin{array}{c}\text { woud } \\
1\end{array}$ & $\begin{array}{c}\text { woud } \\
2\end{array}$ & $\begin{array}{c}\text { woud } \\
3\end{array}$ & & \\
\hline $\begin{array}{c}\text { Rabbit } \\
1\end{array}$ & $1.4 \mathrm{~cm}$ & $1.3 \mathrm{~cm}$ & $1.4 \mathrm{~cm}$ & 4.1 & $\begin{array}{l}1.37 \pm \\
0.06^{*}\end{array}$ \\
\hline $\begin{array}{c}\text { Rabbit } \\
2 \\
\end{array}$ & $1.3 \mathrm{~cm}$ & $1.3 \mathrm{~cm}$ & $1.2 \mathrm{~cm}$ & 3.8 & $\begin{array}{c}0.06 \pm \\
0.06^{*}\end{array}$ \\
\hline $\begin{array}{c}\text { Rabbit } \\
3 \\
\end{array}$ & $1.2 \mathrm{~cm}$ & $1.0 \mathrm{~cm}$ & $1.1 \mathrm{~cm}$ & 3.3 & $\begin{array}{c}1.10 \pm \\
0.10^{*}\end{array}$ \\
\hline $\begin{array}{c}\text { Rabbit } \\
4\end{array}$ & $1.2 \mathrm{~cm}$ & $1.3 \mathrm{~cm}$ & $1.2 \mathrm{~cm}$ & 3.7 & $\begin{array}{l}1.23 \pm \\
0.06^{*}\end{array}$ \\
\hline $\begin{array}{c}\text { Rabbit } \\
5\end{array}$ & $1.8 \mathrm{~cm}$ & $1.7 \mathrm{~cm}$ & $1.7 \mathrm{~cm}$ & 5.2 & $\begin{array}{c}1.73 \pm \\
0.06\end{array}$ \\
\hline
\end{tabular}

Signifying the test group compared with the positive group there was a significant difference (P $<0.05)$.

Research with the wound healing method with the fastest time of 2 weeks was shown by the ointment formula with $75 \%$ extract content. After knowing that the best concentration is the content of the extract of iodine plants $75 \%$. Differences in wound healing due to the location of different wounds between wounds 1 , wounds 2 , and wounds 3 , all three wounds undergo the same phase of the process of efforts to repair the damage that occurs, the inflammatory phase begins from the time of injury until the fifth day. Immediately after the injury, the broken blood vessels constrict and retract with a hemostasis reaction due to aggregation of platelets which together with the fibrin mesh coagulates blood. Plant extracts of iodine 25\%, 50\%, $75 \%$ accelerate the proliferation or fibroplation phase at this time where the fibroblasts are very prominent, the fibroblasts proliferate and synthesize collagen fibers that are formed causing the strength to interlock the wound edges. In this phase granulation, wound contraction and epitalization begin. In the last and longest phase of the wound healing process. A dynamic process occurs in the form of collagen remodeling, wound contraction and scar tissue maturation. The activity of collagen synthesis and degradation is in balance this phase lasts from 3 weeks to 2 years. The end of this healing is obtained a mature scar that has $80 \%$ strength than normal skin. The anatomy of the wound in the part that is often moving or the wound affected by the movement of the healing elasticity of the skin and the diameter of the wound will be different, and the part of the wound that has more fat will make a difference in healing and the diameter of the wound. Wound 1, wound 2, and wound 3 are located parallel to the os vertebrae parallel to the spinal column in the rabbit.

From the results of the table above, it is obtained the percentage of each wound closure which indicates proliferation where the collagen fibers formed cause the strength to interlock the wound edges, significant results are shown on days 7 and 14 on day s the value of wound closure to heal is greater, the difference in wound healing is influenced by fat and anatomic location of the wound. 


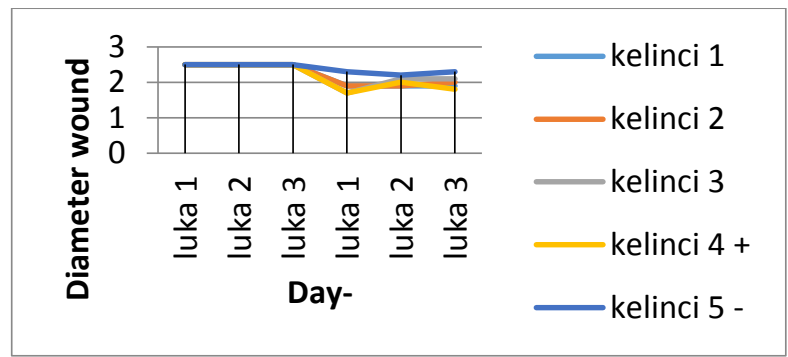

Image Difference in average wound healing on day 7

From the Gerafik data, the average wound healing above the observation on the 7 th day showed that the three test doses had antiuka activity and a significant difference compared to the negative (-) control with a significant value of $\mathrm{p}<0.05$.

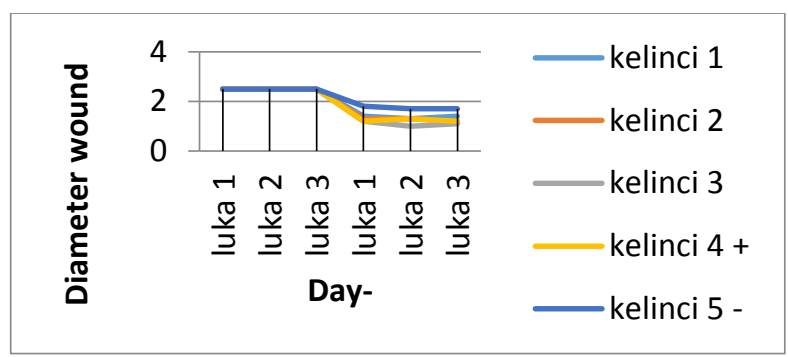

Image Difference in mean wound healing on day 14

Data from the 14th day graph shows the results of the group that was given extract with a concentration of $75 \%$ significantly different from the test group with a concentration of $25 \%$ and a concentration of $50 \%$, a concentration of $75 \%$ aimed at a faster result in wound healing even compared with a positive control group given iodine povidon. Then proceed with the One way Anova test, data on the average length of the wound in rabbits must first be tested for the homogeneity of the data variance, in order to obtain valid data. The results of the variant data obtained significant homogeny> 0.05 where the significant value of 756 on day 7,866 on day 14. The data obtained were homogeneous and could be further tested, namely the One Way ANOVA and LSD tests.

Data that has been done with the One Way ANOVA test, obtained a significant value of 017 on day 7 and 000 on day 17 which means there are significant differences on day 7 and day 14 . ANOVA testing is used as a basis for decision making for which hypothesis is accepted and which hypothesis is rejected based on the comparison of $\mathrm{F}$ arithmetic and $\mathrm{F}$ table, with the condition that if $\mathrm{F}$ arithmetic is greater than $\mathrm{F}$ table then reject $\mathrm{H} 0$ and accept $\mathrm{H} 1$ and if $\mathrm{F}$ count is less than F table then reject H1 Accept H0. From the results of the One Way ANOVA test on the average length of open wounds on Day $7 \mathrm{~F}$ count 5.0603> 2.09 F tables and on day $17 \mathrm{~F}$ count 6.929> 2.09 In rabbits 2 and the hypothesis received by iodine plant extract ointment can heal open wounds on rabbit's back. The LSD (Least Significant Different) test is used to see whether each treatment has significant or not significant differences and also to find out whether the iodine plant has an effect

\section{Conclusions}


Based on this research, it can be concluded that the ointment formulation of iodine plant extracts meets the requirements of ointment quality starting from organoleptic test, homogeneity test and $\mathrm{pH}$ test. Iodine extract ointment $25 \%, 50 \%$ and $75 \%$ provide a healing effect on open wounds on the back of rabbits and the most good effect is shown on $75 \%$ iodine plant extract ointment.

\section{Suggestions}

Suggestions that can be given in this study is the ointment of ethanol extract of iodine plants needs to be done microbiological tests to see the amount of inhibition against bacteria. In addition it is necessary to develop an ethanol extract formulation of iodine plants in the form of other pharmaceutical preparations creams, gels, and pastes. 


\section{References}

[1] Adesola, A., Adetunjin, O.The Efficiacy of Jatropha Multifida In The Management Of Oral Candidiasis: A Prelimilary Study. The Internet Journal of Alternative Medicine. Volume 4. (2007).

[2] Aiyelaagbe.,et all. The Antimicrobial Activity of jatropha multifida Extract and Cromatographic Factions Againts sexually Transmitted Infactions . J. Med, Sci.,8(2): 143147. (2008).

[3] Barbosa, SC, Cilli, EM, Dias, LG. Stabeli, RG, Ciancaglini, P. Asam Amino, Spring. (2010).

[4] Darmadi. Infeksi Nosokomial Problematika Dan Pengendaliannya. Jakarta: Selemba Medika. (2008).

[5] Darmawi, dkk. Daya Hambat Getah Jarak Cina (Jatropha multifida L) Terhadap Staphylococcus aureus Secara IN VITRO. Jurnal ilmiah Fakultas Kedokteran Hewan Universitas Syiah Kuala. Vol .7 no. 2 Banda Aceh. (2013).

[6] Ester Monic. Pedoman Perawatan Pasien. Jakarta: EGC. (2005).

[7] Eka Mulya, Fatimawali, Hosea Jaya Edy. Furmulasi Salep Estrak etanol Daun Telapak Kuda (Ipomea pes-caprae) Dan Uji Efektivitasnya Terhadap Luka Terbuka Pada Punggung Kelinci. Jurnal Ilmiah Farmasi UNSRAT vol.2 no.03 Manado. (2013).

[8] Indonesia Enterostomal Therapy Nurse Association (InETNA) \& Tim Perawat Luka dan Stoma Rumah Sakit Dharmais.Perawatan Luka, Jakarta. (2004).

[9] Grace Riani Pongsipulung, Paulina V.Y. Yamlean. Yos Banne. Formulasi dan Pengujian Salep Ekastrak Bonggol Pisang Ambon (Musa paradisiac var. Sapientum L.) Terhadap Luka Terbuka Pada Kulit Tikus Putih Jantan Galur Wiater. Farmasi FMIPA UNSRAT. Manado. (2012).

[10] Soeraya Dewi Marliana, Venty Suryanti. Analisis Kromatografi Lapis tipis komponen kimia buah labu siam (Sechium Edule Jacd. Swartz) Dalam Ekstrak Etanol. Biologi FMIPA UNS Surakarta. (2005).

[11] Moya J. Marison. Menejemen Luka. Jakarta : EGCV. (2003).

[12] Niswah Paju, PaulinV.Y. Yamelian, Novel Kojong. 2013. Uji Aktivitas Salep Estrak Daun Binahong (Anredera cordifolia Ten Steenis) Pada Kelinci Yang Terinfeksi Bakteri Staphylococcus laureus. Jurnal Ilmiah Farmasi, UNSRAT Vol. 2 No.01 Manado. (2003).

[13] Nuraini, Widjajanti Ap. Obat-Obatan. Yogyakarta: Kansius. (2004).

[14] Roosita, Katrin., dkk. Penggunaan Tanaman Obat Oleh Pengobat Tradisional Di Wilayah Hutan Wisata Curuk Nangka Bogor. Dapartemen of Human E cology, School of International Health, The University of Tokyo press. Tokyo. (2009).

[15] Yunes M. Bonay. Pemanfaatan Jenis-Jenis Obat Tradisional Oleh Masyarakat Suku Klabra Di Kampung Buk Distrik Klabot Kabupaten Sorong. Skripsi. Manokwari. Fakultas Kehutanan Universitas Negri. (2013). 



